\title{
Risk impact of edoxaban in the management of stroke and venous thromboembolism
}

\author{
This article was published in the following Dove Press journal: \\ Vascular Health and Risk Management \\ II August 2016 \\ Number of times this article has been viewed
}

\section{Katherine $\mathrm{V}$ Hurst John Matthew O'Callaghan Ashok Handa \\ Nuffield Department of Surgical Sciences, University of Oxford, Oxford, UK}

\begin{abstract}
The new generation of target-specific oral anticoagulants is being prescribed for increasing numbers of patients at risk of stroke or venous thromboembolism (VTE). These drugs offer valuable benefits due to fast onset anticoagulation, a fixed anticoagulation effect (allowing administration of specified doses), and no requirement for routine monitoring. Edoxaban is a fast-acting oral anticoagulant, approved for use in the prevention of stroke in patients with nonvalvular atrial fibrillation (AF) and in the treatment of acute VTE. Like many of the new oral anticoagulants, it selectively inhibits factor $\mathrm{Xa}$, in a concentration-dependent manner. Multiple Phase II clinical trials have shown edoxaban to be noninferior to vitamin $\mathrm{K}$ antagonists in the prevention of stroke and VTE, with a good safety profile. To date, the pivotal studies to endorse edoxaban's clinical use have been ENGAGE AF-TIMI and Hokusai-VTE, both of which have compared its efficacy to standard warfarin treatment. This paper aims at reviewing the use of edoxaban in the management of stroke and thromboembolic disease, highlighting the key study results that have led to its current license.
\end{abstract}

Keywords: edoxaban, stroke management, venous thromboembolism, atrial fibrillation, randomized controlled trials, new oral anticoagulants

\section{History and development}

Patients are prescribed oral anticoagulants for a variety of medical conditions, including, but not limited to, atrial fibrillation (AF), acute venous thromboembolism (VTE), secondary prevention of stroke and myocardial infarction, and VTE prophylaxis. Warfarin (an antagonist of vitamin K-dependent clotting factors, VKA) had previously been the mainstay for long-term anticoagulation as its effect could be easily quantified, it could be reversed if required, and its long-term sequelae were well understood. VKAs, however, have multiple limitations due to their delayed anticoagulation effects, variability in dosing, drug and food interactions, and requirement for frequent monitoring. ${ }^{1,2}$ Several studies have also shown VKAs to be ineffective in up to half the patients for the treatment of VTE, due to their unreliability, slow onset of action, and need for stringent patient cooperation. ${ }^{3}$

Since 2008, new oral anticoagulants (NOACs) have been increasingly used in clinical settings. Their fixed anticoagulation response and regular dosing regimens are fast becoming favored by clinicians. ${ }^{4,5}$

The majority of NOACs work by selectively targeting factor Xa, a molecule responsible for the activation of thrombin in the clotting cascade. The exception to this is dabigatran, which acts on thrombin directly.
Nuffield Department of Surgical Sciences, John Radcliffe Hospital, Headley Way, Oxford OX3 9DU, UK

Tel +44I865220302

Fax +441865 768876

Email ashok.handa@nds.ox.ac.uk 
Multiple randomized controlled trials (RCTs) have shown all NOACs to be equivalent to standard warfarin therapy, with equivocal or reduced rates of stroke $\mathrm{e}^{6,7}$ and comparable rates of arterial embolism. ${ }^{8,9}$

Bleeding complications have been shown to be similar between the two medications but significantly reduced rates of intracerebral hemorrhage and overall mortality have been documented following the use of NOACs. ${ }^{2,10,11}$

Consequently, after many years with only one treatment option available, the NOACs now provide a safe alternative to warfarin. Listed below are the current NOAC licenses (UK):

- Dabigatran: for stroke prevention in patients with $\mathrm{AF}+$ one CHADS (congestive heart failure, hypertension, age $=75$ years, diabetes mellitus, stroke) risk factor $(150 \mathrm{mg}$ twice daily $[\mathrm{BD}])$, the treatment of deep vein thrombosis (DVT) or pulmonary embolism (PE) after parenteral anticoagulation for 5-10 days (150 mg BD), and prevention of VTE in elective hip/knee surgery (110 mg 1-4 hours after surgery, then $220 \mathrm{mg}$ once daily [OD] 9/7).

- Rivaroxaban: for prevention of VTE in elective hip/knee surgery (10 mg OD), stroke prevention in patients with AF + one CHADS risk factor (20 mg OD), and treatment of DVT and PE (15 mg BD), or prophylaxis after recurrent DVT/PE (20 mg OD).

- Apixaban: for prevention of VTE in elective hip/knee surgery $(2.5 \mathrm{mg})$ and stroke prevention in patients with $\mathrm{AF}+$ one CHADS risk factor $(5 \mathrm{mg})$.

The European Society of Cardiology and the American Heart Association (AHA) updated their guidelines in 2012 and 2014, respectively, to include NOACs in the management of AF. ${ }^{12,13}$ The American College of Chest Physicians followed in 2012 by advising the use of NOACs for the treatment for VTE, ${ }^{14}$ and licenses for all the aforementioned have been approved by the National Institute of Clinical Excellence (NICE).

Edoxaban is the newest inhibitor of factor Xa to complete Phase III trials. It was developed by Daiichi Sankyo, and gained its first license in Japan in 2011 for the prevention of VTE after lower limb surgery. ${ }^{15}$ Following the clinical license of dabigatran, rivaroxaban, and apixaban, both the US and the UK have more recently approved edoxaban for the prevention of AF-related strokes and VTE.

Phase I studies concluded that single doses from 10 up to $150 \mathrm{mg}$, and multiple doses up to $120 \mathrm{mg}$, were safe and well tolerated. Following multiple Phase II studies, the two key Phase III studies, ENGAGE F-TIMI ${ }^{16}$ and Hokusai VTE,${ }^{17}$ have been key in the introduction of edoxaban into clinical practice.

\section{Pharmacokinetics}

Edoxaban is a direct factor Xa inhibitor, with a predictable anticoagulation profile. Its peak effects are seen within 1-2 hours, and studies have shown elevated baseline levels for up to 24 hours after administration (half-life 10-14 hours). ${ }^{18}$ Although once-daily and twice-daily dosing regimens have been trialed, greater bleeding risks were associated with twice-daily prescriptions. ${ }^{19}$

Edoxaban is predominantly eliminated in feces and urine, but renal elimination ranges from $35 \%$ to $50 \%{ }^{18}$ In patients with renal impairment, dose reduction should also be considered. ${ }^{20}$ Table 1 provides summary information of edoxaban.

Table I Edoxaban: summary information

\begin{tabular}{|c|c|}
\hline Mode of action & Direct inhibitor of factor $\mathbf{X a}$ \\
\hline Indication/license & $\begin{array}{l}\text { Treatment of DVT or PE and prevention of } \\
\text { recurrence of symptomatic VTE } \\
\text { Prevention of stroke and systemic embolic events } \\
\text { in patients with AF }\end{array}$ \\
\hline Dosage & $30-60 \mathrm{mg}$ \\
\hline Dose regimen & Once \\
\hline Reversal & $\begin{array}{l}\text { Specific reversal not available. Consider } \\
\text { prothrombin complex concentrate in emergency } \\
\text { setting }\end{array}$ \\
\hline Monitoring & No routine monitoring required \\
\hline $\begin{array}{l}\text { Periprocedure } \\
\text { management }\end{array}$ & $\begin{array}{l}\text { Edoxaban should be discontinued a minimum of } \\
\text { I } 2 \text { hours prior to procedure, and enoxaparin } \\
\text { commenced at the same time as the next } \\
\text { scheduled NOAC dose }\end{array}$ \\
\hline Prodrug & $\begin{array}{l}\text { None; edoxaban is a direct factor } \mathrm{Xa} \text { inhibitor and } \\
\text { active upon administration }\end{array}$ \\
\hline Half-life & $10-14$ hours \\
\hline Peak serum levels & $\mathrm{I}-2$ hours \\
\hline Excretion & $\begin{array}{l}\text { Excretion predominantly in feces and urine } \\
\text { Approximately } 35 \% \text { renal elimination }\end{array}$ \\
\hline Use in pregnancy & $\begin{array}{l}\text { Not recommended. Risks cannot be ruled out at } \\
\text { present }\end{array}$ \\
\hline $\begin{array}{l}\text { Reduces efficacy of } \\
\text { edoxaban, risk of } \\
\text { stroke/embolism }\end{array}$ & $\begin{array}{l}\text { CYP3A4 and P-gP inhibitors: HIV protease } \\
\text { inhibitors, itraconazole, ketoconazole, } \\
\text { clarithromycin }\end{array}$ \\
\hline $\begin{array}{l}\text { Increases edoxaban } \\
\text { serum levels, risk } \\
\text { of bleeding }\end{array}$ & $\begin{array}{l}\text { CYP3A4 and P-gP inducers: carbamazepine, } \\
\text { phenytoin, rifampicin } \\
\text { Avoid edoxaban administration }\end{array}$ \\
\hline Dose in renal & $50 \%$ dose reduction if GFR is $15-29 \mathrm{~mL} / \mathrm{min}$ \\
\hline $\begin{array}{l}\text { impairment } \\
\text { Bridging }\end{array}$ & $\begin{array}{l}\text { Do not use if GFR }<15 \mathrm{~mL} / \mathrm{min} \\
\text { Edoxaban should be discontinued and enoxaparin }\end{array}$ \\
\hline Bridging & $\begin{array}{l}\text { Edoxaban should be discontinued and enoxaparin } \\
\text { commenced at the same time as the next } \\
\text { scheduled NOAC dose } \\
\text { For conversion to warfarin, edoxaban should } \\
\text { be discontinued once the patient's INR is in } \\
\text { therapeutic range }\end{array}$ \\
\hline Monitoring & $\begin{array}{l}\text { aPTT and PT and anti-factor } \mathrm{Xa} \text { are all sensitive to } \\
\text { edoxaban concentrations }\end{array}$ \\
\hline
\end{tabular}

Abbreviations: DVT, deep vein thrombosis; $\mathrm{PE}$, pulmonary embolism; $\mathrm{VTE}$, venous thromboembolism; P-gp, P-glycoprotein; AF, atrial fibrillation; GFR, glomerular filtration rate; NOAC, new oral anticoagulant; INR, international normalized ratio; aPTT, activated partial thromboplastin time; PT, prothrombin time. 
Although edoxaban has minimal drug and food interactions, it is affected by drugs that inhibit the p-glycoprotein (P-gp) transport protein. Consequently, when taken in combination with such drugs, a dose reduction of $50 \%$ is recommended. ${ }^{21}$

\section{Efficacy in stroke prevention}

$\mathrm{AF}$ is one of the most prevalent cardiac conditions, associated with a four to five times increased relative risk of ischemic stroke. ${ }^{22}$ Consequently, oral anticoagulant therapies have been used in patients with nonvalvular AF for many years, and they are recommended in all those who have had a prior stroke or transient ischemic attack, or have an increased risk of ischemic event determined by the $\mathrm{CHAD}_{2} \mathrm{~S}_{2}$-VASc score. ${ }^{23}$

There have been four major RCTs comparing edoxaban to warfarin in the prevention of stroke in nonvalvular AF. Results of these studies are summarized in Tables 2 and 3. All the RCTs included patients with nonvalvular AF and $\mathrm{CHAD}_{2} \mathrm{~S}_{2}$-VASc score of $>1$.

Table 2 RCT comparing edoxaban to warfarin therapy in the prevention of AF-related ischemic strokes

\begin{tabular}{|c|c|c|c|}
\hline Study & Study information & Jadad score & Key outcomes (numbers expressed as \%) \\
\hline \multirow[t]{19}{*}{ Weitz et al ${ }^{19}$} & Number of participants; I, I46 & 5 & Edoxaban OD noninferior to warfarin. \\
\hline & Randomized open-label drug, double blinded & & Bleeding: \\
\hline & 3-month follow-up & & 30 mg OD; $5.5(P=0.367)$ \\
\hline & Comparison: & & $30 \mathrm{mg} \mathrm{BD;} 12.7(P=0.104)$ \\
\hline & Edoxaban 30 mg OD (N: 235) & & $60 \mathrm{mg}$ OD; $3.9(P=0.864)$ \\
\hline & Edoxaban 30 mg BD (N: 245) & & $60 \mathrm{mg} \mathrm{BD} ; 18.3(P=0.002)$ \\
\hline & Edoxaban 60 mg OD (N: 235) & & Warfarin; 8.0 \\
\hline & 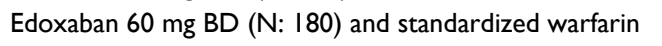 & & Major bleeding: \\
\hline & therapy INR 2-3 (N: 25I) & & 30 mg OD; $3.0(P=1.0)$ \\
\hline & & & 30 mg BD; $7.8(P=0.029)$ \\
\hline & & & 60 mg OD; $3.9(P=0.807)$ \\
\hline & & & $60 \mathrm{mg} \mathrm{BD} ; 10.6(P=0.002)$ \\
\hline & & & Warfarin; 3.2 \\
\hline & & & Major cardiovascular event: \\
\hline & & & $30 \mathrm{mg}$ OD; 1.7 \\
\hline & & & 30 mg BD; 2.5 \\
\hline & & & 60 mg OD; 4.3 \\
\hline & & & 60 mg BD; I.I \\
\hline & & & Warfarin; 2.4 \\
\hline \multirow[t]{13}{*}{ Chung et $\mathrm{a}^{24}$} & Number of participants; 234 & 5 & Edoxaban noninferior to warfarin. \\
\hline & Randomized open-label, double-blinded dose. 3-month & & Bleeding: \\
\hline & follow-up & & 30 mg OD; 20.3 \\
\hline & Comparison: & & $60 \mathrm{mg}$ OD; 23.8 \\
\hline & Edoxaban $30 \mathrm{mg}$ OD & & Warfarin; 29.3 \\
\hline & Edoxaban 60 mg OD to warfarin (INR 2-3) & & Major bleeding: \\
\hline & & & $30 \mathrm{mg}$ OD; 0 \\
\hline & & & 60 mg OD; 7.5 \\
\hline & & & Warfarin; 6.6 \\
\hline & & & Major cardiovascular event: \\
\hline & & & $30 \mathrm{mg}$ OD; 2.5 \\
\hline & & & 60 mg OD; 3.8 \\
\hline & & & Warfarin; I.3 \\
\hline \multirow[t]{11}{*}{ Yamashita et a ${ }^{25}$} & Number of participants; 546 & 5 & Edoxaban noninferior to warfarin. \\
\hline & Randomized, double-blinded trial. 3-month follow-up & & Bleeding: \\
\hline & Comparison: & & 30 mg OD; 18.5 \\
\hline & Edoxaban $30 \mathrm{mg}$ OD & & 45 mg OD; 22.4 \\
\hline & Edoxaban $45 \mathrm{mg}$ OD & & 60 mg OD; 27.7 \\
\hline & Edoxaban $60 \mathrm{mg}$ OD with warfarin treatment (INR 2-3) & & Warfarin; 20 \\
\hline & & & Major bleeding: \\
\hline & & & 30 mg OD; 1.5 \\
\hline & & & 45 mg OD; 5.2 \\
\hline & & & 60 mg OD; 5.4 \\
\hline & & & Warfarin; 3.2 \\
\hline
\end{tabular}

Abbreviations: $\mathrm{BD}$, twice daily; $\mathrm{OD}$, once daily; RCTs, randomized controlled trials; AF, atrial fibrillation; INR, international normalized ratio. 
Weitz et al ${ }^{19}$ followed 1,146 patients over a 3-month period. Both 30 and $60 \mathrm{mg}$ doses were trialed in once- and twice-daily regimens, and were compared to a group of patients on standard warfarin treatment (international normalized ratio: 2-3). The study was double blinded to the dose of edoxaban but open label to those on edoxaban and warfarin. Results showed that once-daily dosing regimens were of the same efficacy and safety as warfarin (major bleeding $60 \mathrm{mg} ; 3.0[P=0.807], 30 \mathrm{mg} ; 3.0[P=1.0]$ warfarin 3.2$)$, but twice-daily regimens were associated with an increased risk of bleeding $(10.6 \%, P=0.002$ for $60 \mathrm{mg}$ and $7.8 \%, P=0.029$ for $30 \mathrm{mg}$ ).

Both Chung et al and Yamashita et al showed edoxaban to be noninferior to warfarin at $30 \mathrm{mg} \mathrm{OD}, 45 \mathrm{mg} \mathrm{OD}$, and $60 \mathrm{mg}$ OD dosing regimes..$^{24,25}$

However, the key study so far assessing the use of edoxaban in AF-related stroke prevention is the ENGAGE-AF

Table 3 The key outcomes of the ENGAGE-AF TIMI 48 trial, ${ }^{16}$ comparing edoxaban 30 and $60 \mathrm{mg}$ to warfarin treatment

\begin{tabular}{|c|c|c|c|c|}
\hline Complications & $\begin{array}{l}\text { Low-dose } \\
\text { edoxaban } \\
(30 \mathrm{mg})\end{array}$ & $\begin{array}{l}\text { High-dose } \\
\text { edoxaban } \\
(60 \mathrm{mg})\end{array}$ & $\begin{array}{l}\text { Warfarin } \\
\text { (therapeutic) }\end{array}$ & Outcome \\
\hline $\begin{array}{l}\text { Stroke and } \\
\text { embolism } \\
\text { prevention }\end{array}$ & $\begin{array}{l}\mathrm{I} .6 \mathrm{I} \% \\
(P=0.005)\end{array}$ & $\begin{array}{l}\text { I. } 18 \% \\
(P=0.00 \mathrm{I})\end{array}$ & $1.50 \%$ & $\begin{array}{l}\text { Reduced by } \\
\text { up to } 0.32 \%\end{array}$ \\
\hline Bleeding rates & $\begin{array}{l}1.61 \% \\
(P=0.001)\end{array}$ & $\begin{array}{l}2.75 \% \\
(P=0.001)\end{array}$ & $3.43 \%$ & $\begin{array}{l}\text { Reduced by } \\
\text { up to } 1.82 \%\end{array}$ \\
\hline $\begin{array}{l}\text { Intracranial } \\
\text { hemorrhage }\end{array}$ & $\begin{array}{l}0.26 \% \\
(P=0.001)\end{array}$ & $\begin{array}{l}0.39 \% \\
(P=0.001)\end{array}$ & $0.85 \%$ & $\begin{array}{l}\text { Reduced by } \\
\text { up to } 0.59 \%\end{array}$ \\
\hline $\begin{array}{l}\text { Cardiovascular } \\
\text { death }\end{array}$ & $\begin{array}{l}2.71 \% \\
(P=0.008)\end{array}$ & $\begin{array}{l}2.74 \% \\
(P=0.013)\end{array}$ & $3.17 \%$ & $\begin{array}{l}\text { Reduced by } \\
\text { up to } 0.46 \%\end{array}$ \\
\hline
\end{tabular}

TIMI 48 trial. ${ }^{16}$ This study included 21,105 patients who were randomized to 30 or $60 \mathrm{mg}$ edoxaban OD, compared to standardized warfarin therapy, for 3-12 months. The study was randomized, double blinded, and included patients with a moderate-to-high risk of stroke $\left(\mathrm{CHADS}_{2}\right.$ score $\left.\geq 2\right)$. Results showed that both 30 and $60 \mathrm{mg}$ doses of edoxaban were noninferior to warfarin in the prevention of stroke and systemic embolism. Study outcomes are tabulated in Table 3.

In light of these results, the ENGAGE-AF TIMI 48 trial conclusions recommended edoxaban $60 \mathrm{mg}$ for the prevention of AF-related strokes and $30 \mathrm{mg}$ for those patients with high bleeding risk.

\section{Efficacy in prevention of VTE}

VTE most commonly presents as either a DVT or PE and has an estimated mortality of up to 25,000 deaths annually in the UK. ${ }^{26}$ It also costs the National Health Service approximately $£ 640$ million per year. ${ }^{27}$ In light of this, prophylactic subcutaneous low-molecular-weight heparin has been recommended by the National Institute of Clinical Excellence for the prevention of VTE in all those at risk. ${ }^{28}$

Three Phase III clinical trials have evaluated the use of edoxaban in the prevention of VTE, including a combined total of 1,418 patients (Table 4). STARS E-3, STARS J-4, and STARS J-V were all randomized, double-blinded studies in patients undergoing orthopedic surgery, and they compared edoxaban $30 \mathrm{mg}$ once daily to enoxaparin $20 \mathrm{mg}$ twice daily. All three RCTs showed no significant difference in bleeding rates between the two treatments, and both STARS E-3 and

Table 4 Evidence for edoxaban in the prevention of VTE, including RCTs and meta-analysis

\begin{tabular}{|c|c|c|c|}
\hline Study & Study information & $\begin{array}{l}\text { Jadad } \\
\text { score }\end{array}$ & Key outcomes (numbers expressed as \%) \\
\hline $\begin{array}{l}\text { Robertson } \\
\text { et } \mathrm{al}^{3 \text { I }}\end{array}$ & $\begin{array}{l}\text { Number of participants: } 27,945 \\
\text { II RCTs } \\
\text { Three studies on direct thrombin inhibitors, eight studies on oral factor } \\
\text { Xa inhibitors; (four rivaroxaban, two apixaban, and two edoxaban) }\end{array}$ & $\mathrm{n} / \mathrm{a}$ & $\begin{array}{l}\text { Oral factor Xa inhibitors demonstrated a similar } \\
\text { rate of recurrent VTE compared to warfarin } \\
\text { (OR } 0.89 ; 95 \% \mathrm{Cl} 0.73-1.07) \text { and a lower rate of } \\
\text { recurrent DVT (OR } 0.75 ; 95 \% \mathrm{Cl} 0.57-0.98)\end{array}$ \\
\hline $\begin{array}{l}\text { Fuji et al } \\
(\text { STARS E-3) }\end{array}$ & $\begin{array}{l}\text { Number of participants: } 716 \\
\text { RCT. All patients undergoing unilateral total knee arthroscopy } \\
\text { Comparison: edoxaban } 30 \mathrm{mg} \text { and subcutaneous enoxaparin } 20 \mathrm{mg} \mathrm{BD}\end{array}$ & 5 & $\begin{array}{l}\text { Edoxiban superior when compared to } \\
\text { enoxaparin in the prevention of VTE. Absolute } \\
\text { risk reduction of } 6.5 \% \\
\text { Efficacy: } 7.4 \text { vs } 13.0(P<0.00 \mid) \\
\text { Safety: } 6.2 \text { vs } 3.7(P=0.129)\end{array}$ \\
\hline $\begin{array}{l}\text { Fuji et al } \\
(\text { STARS J-4) }\end{array}$ & $\begin{array}{l}\text { Number of participants: } 92 \\
\text { RCT. Patients undergoing surgery for trochanteric or subtrochanteric } \\
\text { fractures } \\
\text { Edoxaban } 30 \mathrm{mg} \text { compared to subcutaneous enoxaparin } 20 \mathrm{mg} \mathrm{BD}\end{array}$ & 5 & $\begin{array}{l}\text { Rates of VTE with edoxaban and enoxaparin } \\
\text { were } 6.5 \% \text { and } 3.7 \% \text {, respectively, and bleeding } \\
\text { rates were } 3.4 \% \text { and } 6.9 \% \text {, respectively }\end{array}$ \\
\hline $\begin{array}{l}\text { Fuji et al } \\
(\text { STARS J-V) }\end{array}$ & $\begin{array}{l}\text { Number of participants: } 610 \\
\text { Phase III, double-blinded study. Patients undergoing elective, unilateral total } \\
\text { knee arthroplasty } \\
\text { Edoxaban } 30 \mathrm{mg} \text { OD or enoxaparin } 2,000 \mathrm{IU} \text { twice daily for II-14 days. }\end{array}$ & 5 & $\begin{array}{l}\text { Edoxaban superior to subcutaneous enoxaparin } \\
\text { in the prevention of VTE; } 2.4 \text { vs } 6.9 \text { ( } P=0.0157) \text {. } \\
\text { Major or clinically relevant nonmajor bleeding; } \\
2.6 \text { vs } 3.7(0.465)\end{array}$ \\
\hline
\end{tabular}

Abbreviations: $\mathrm{BD}$, twice daily; $\mathrm{Cl}$, confidence interval; DVT, deep vein thrombosis; OD, once daily; OR, odds ratio; RCTs, randomized controlled trials; VTE, venous thromboembolism; n/a, not applicable; IU, international units. 
STARS J-V proved edoxaban to be superior in the prevention of VTE. ${ }^{29,30}$

Robertson et a ${ }^{31}$ reviewed a total of 27,945 patients (from eleven RCTs) and demonstrated a similar rate of recurrent DVT with the use of edoxaban compared to enoxaparin. A lower rate of recurrent DVT was also observed.

The results of the RCT STARS E- $3^{29}$ compared 716 patients following knee arthroscopy and showed edoxaban to be superior to enoxaparin in the prevention of DVT (overall risk reduction of $6.5 \%$ ).

STARS J-4 compared edoxaban to enoxaparin following trochanteric and subtrochanteric fractures. ${ }^{32}$ Rates of VTE with edoxaban and enoxaparin were $6.5 \%$ and $3.7 \%$, respectively, and bleeding rates were $3.4 \%$ and $6.9 \%$.

Patients undergoing elective, unilateral total knee arthroplasty were compared in the STARS J-V RCT. ${ }^{30}$ Six hundred and ten patients were randomized, and outcomes showed edoxaban to be superior to enoxaparin in both prevention of DVT and major bleeding risk.

\section{Efficacy in treatment of VTE}

For the treatment of VTE, the largest randomized, doubleblinded Phase III clinical trial is the Hokusai VTE study. ${ }^{17}$ This study evaluated whether 5 days of heparin treatment followed by $60 \mathrm{mg}$ once-daily edoxaban would be a superior alternative to warfarin therapy for the prevention of recurrent thromboembolism.

In patients with VTE (including PE with right ventricular dysfunction), treatment with heparin followed by oral edoxaban $60 \mathrm{mg}$ once daily was shown to be noninferior to the standard treatment. With respect to bleeding, results were superior for edoxaban: $8.5 \%$ vs $10.3 \%(P=0.004)$.

Hokusai VTE also showed that a reduced dose $(30 \mathrm{mg}$ OD) of edoxaban is safe in patients with renal impairment and low body weight. Results are summarized in Table 5 .

\section{Safety}

As described earlier, the clinical trials of edoxaban efficacy have also reported on the drug safety profile. In combination with the results of large meta-analyses (Table 6), edoxaban has been shown to be safe in the current recommended doses.

Because of the pharmacokinetics of NOACs, there are no suitable reversal therapies in the setting of acute bleeding. ${ }^{33,34}$ Thus, the same protocol as for major bleeding in warfarin must be adhered to: discontinue the drug, apply manual compression, maintain blood pressure, surgical/ radiological intervention if appropriate, and replace blood products \pm prothombin complex concentrate. ${ }^{35}$ It is possible
Table 5 Trial information for Nakamura et al - the only RCT comparing edoxaban to enoxaparin and warfarin therapy in the treatment of VTE

\begin{tabular}{|c|c|c|c|}
\hline $\begin{array}{l}\text { Study } \\
\text { name }\end{array}$ & $\begin{array}{l}\text { Number of } \\
\text { participants }\end{array}$ & $\begin{array}{l}\text { Jadad } \\
\text { score }\end{array}$ & $\begin{array}{l}\text { Key outcomes } \\
\text { (numbers expressed } \\
\text { as \%) }\end{array}$ \\
\hline $\begin{array}{l}\text { Nakamura } \\
\text { et a }\left.\right|^{37}\end{array}$ & $\begin{array}{l}\text { 8,292 patients from } 439 \\
\text { centers worldwide } \\
\mathrm{RCT} \text {, double blinded of } \\
\text { patients with DVT } \pm \mathrm{PE} \\
\text { Edoxaban } 60 \mathrm{mg} \mathrm{OD} \\
\text { compared to warfarin } \\
\text { therapy. (For patients } \\
\text { with } \mathrm{CrCl} 30-50 \mathrm{~mL} \text { or } \\
\text { weight }<60 \mathrm{~kg} 50 \% \text { dose } \\
\text { reduction in edoxaban) }\end{array}$ & 5 & $\begin{array}{l}\text { Edoxaban noninferior in } \\
\text { efficacy to warfarin but } \\
\text { superior when comparing } \\
\text { bleeding complications } \\
\text { VTE: } \\
\text { Edoxaban } 3.2 \\
\text { Warfarin } 3.5 \\
\text { Bleeding: } \\
\text { Edoxaban } 8.5 \\
\text { Warfarin } 10.3\end{array}$ \\
\hline
\end{tabular}

Abbreviations: RCT, randomized controlled trial; VTE, venous thromboembolism; DVT, deep vein thrombosis; OD, once daily; PE, pulmonary embolism.

Table 6 Meta-analyses reporting on the safety of edoxaban in comparison to alternative oral anticoagulants

\begin{tabular}{|c|c|c|c|}
\hline Study & $\begin{array}{l}\text { Trial } \\
\text { information }\end{array}$ & Comparators & Key outcomes \\
\hline $\begin{array}{l}\text { Caldeira } \\
\text { et a }\left.\right|^{38}\end{array}$ & $\begin{array}{l}\text { Meta-analysis } \\
\text { of eleven } \\
\text { Phase III } \\
\text { RCTs }\end{array}$ & $\begin{array}{l}\text { Comparison } \\
\text { of NOACs } \\
\text { with VKAs or } \\
\text { low-molecular- } \\
\text { weight heparin } \\
\text { followed by } \\
\text { VKAs }\end{array}$ & $\begin{array}{l}\text { NOACs decrease the risk } \\
\text { of fatality in cases related } \\
\text { to major bleeding events, } \\
\text { particularly in AF patients } \\
\text { Results support the safety } \\
\text { profile of NOACs even } \\
\text { without having a widely } \\
\text { available drug-specific } \\
\text { antidote }\end{array}$ \\
\hline $\begin{array}{l}\text { Loffredo } \\
\text { et } \mathrm{al}^{39}\end{array}$ & $\begin{array}{l}\text { Meta-analysis } \\
\text { of eleven } \\
\text { RCTs (29,482 } \\
\text { patients) }\end{array}$ & $\begin{array}{l}\text { Comparison } \\
\text { of } 30 \text { and } 60 \\
\mathrm{mg} \text { doses of } \\
\text { edoxaban } \\
\text { with warfarin, } \\
\text { for rates of } \\
\text { recurrent VTE } \\
\text { and death }\end{array}$ & $\begin{array}{l}\text { Treatment with NOACs in } \\
\text { patients with acute VTE is } \\
\text { noninferior to conventional } \\
\text { therapy with warfarin for } \\
\text { recurrent VTE or death, but } \\
\text { there might be an increased } \\
\text { incidence of myocardial } \\
\text { infarction }\end{array}$ \\
\hline $\begin{array}{l}\text { Sardar } \\
\text { et } \mathrm{al}^{40}\end{array}$ & $\begin{array}{l}\text { Meta-analysis } \\
\text { of } 50 \text { RCTs } \\
\text { (I55,537 } \\
\text { patients) }\end{array}$ & $\begin{array}{l}\text { Comparison } \\
\text { of NOACs } \\
\text { (rivaroxaban, } \\
\text { dabigatran, } \\
\text { apixaban, } \\
\text { edoxaban, and } \\
\text { darexaban) } \\
\text { with VKAs }\end{array}$ & $\begin{array}{l}\text { No significant difference } \\
\text { between NOACs and } \\
\text { comparators in the } \\
\text { treatment of AF and } \\
\text { extended treatment of VTE } \\
\text { NOACs caused significantly } \\
\text { less major bleeding } \\
\text { compared to VKAs. } \\
\text { Risk of major bleeding varied } \\
\text { with indication for use } \\
\text { NOACs may increase the } \\
\text { risk of major bleeding after } \\
\text { hip surgery, ACS and acute } \\
\text { medically ill patients, but } \\
\text { may be associated with less } \\
\text { bleeding in treatment of } \\
\text { acute VTE/PE }\end{array}$ \\
\hline
\end{tabular}

Abbreviations: RCTs, randomized controlled trials; VTE, venous thromboembolism; PE, pulmonary embolism; VKAs, vitamin $\mathrm{K}$ antagonists; NOACs, new oral anticoagulants; AF, atrial fibrillation; ACS, acute coronary syndromes. 
to administer activated charcoal orally if the anticoagulant was taken within 2 hours. Tranexamic acid should also be considered following the result of the CRASH-2 trial. ${ }^{35,36}$

\section{Conclusion}

The NOACs are quickly becoming the preferred treatment in the prevention and management of thromboembolic disease. Edoxaban is a once-daily oral factor Xa inhibitor with fast onset and the added benefit of fixed anticoagulation profiling without routine monitoring. Phase III clinical trials for its use in AF-related strokes (ENGAGE AF-TIMI 48) and VTE treatment (Houkusai VTE) have shown noninferior efficacy compared to standard therapy, as well as reduced rates of bleeding and cardiovascular death. Further studies have also confirmed safe use in both 30 and $60 \mathrm{mg}$ doses.

From the results of multiple RCTs and systematic reviews, edoxaban appears to be a safe and effective alternative treatment to oral coagulation in the clinical setting. However, further developments are always pending. In October 2015, we saw the introduction of the first reversal agent for dabigatran "Praxbind" (idarucizumab; Boehringer Ingelheim, Ingelheim, Germany), and pharmaceutical companies are trialing reversal agents for the factor Xa inhibitors. There are now multiple new options for the management of acute and chronic medical conditions for which we previously could only realistically recommend warfarin in the long term. The focus of clinical trials on both safety and efficacy has facilitated the expansion of edoxaban in clinical practice.

Of the NOACs, edoxaban appears to have the best evidence base for efficacy and safety. The NOACs are here to stay, and physicians and surgeons alike need to learn how to use them optimally for patient safety and benefit.

\section{Disclosure}

The authors report no conflicts of interest in this work.

\section{References}

1. Miller CS, Grandi SM, Shimony A, et al. Meta-analysis of efficacy and safety of new oral anticoagulants (dabigatran, rivaroxaban, apixaban) versus warfarin in patients with atrial fibrillation. Am J Cardiol. 2012;110(3):453-460.

2. Ruff CT, Giugliano RP, Braunwald E, et al. Comparison of the efficacy and safety of new oral anticoagulants with warfarin in patients with atrial fibrillation: a meta-analysis of randomised trials. Lancet. 2014;383(9921):955-962.

3. Wilke T, Groth A, Mueller S, et al. Oral anticoagulation use by patients with atrial fibrillation in Germany. Adherence to guidelines, causes of anticoagulation under-use and its clinical outcomes, based on claimsdata of 183,448 patients. Thromb Haemost. 2012;107(6):1053-1065.

4. Schneeweiss S, Gagne JJ, Patrick AR, et al. Comparative efficacy and safety of new oral anticoagulants in patients with atrial fibrillation. Circ Cardiovasc Qual Outcomes. 2012;5(4):480-486.
5. Yeh CH, Gross PL, Weitz JI. Evolving use of new oral anticoagulants for treatment of venous thromboembolism. Blood. 2014;124(7):1020-1028.

6. Easton JD, Lopes RD, Bahit MC, et al. Apixaban compared with warfarin in patients with atrial fibrillation and previous stroke or transient ischaemic attack: a subgroup analysis of the ARISTOTLE trial. Lancet Neurol. 2012;11(6):503-511.

7. Halvorsen S, Atar D, Yang H, et al. Efficacy and safety of apixaban compared with warfarin according to age for stroke prevention in atrial fibrillation: observations from the ARISTOTLE trial. Eur Heart J. 2014;35(28):1864-1872.

8. Lopes RD, Alexander JH, Al-Khatib SM, et al. Apixaban for reduction in stroke and other ThromboemboLic events in atrial fibrillation (ARISTOTLE) trial: design and rationale. Am Heart J. 2010;159(3): 331-339.

9. Halperin JL, Hankey GJ, Wojdyla DM, et al. Efficacy and safety of rivaroxaban compared with warfarin among elderly patients with nonvalvular atrial fibrillation in the Rivaroxaban Once Daily, Oral, Direct Factor Xa Inhibition Compared With Vitamin K Antagonism for Prevention of Stroke and Embolism Trial in Atrial Fibrillation (ROCKET AF). Circulation. 2014;130(2):138-146.

10. Hart RG, Diener HC, Yang S, et al. Intracranial hemorrhage in atrial fibrillation patients during anticoagulation with warfarin or dabigatran: the RE-LY trial. Stroke. 2012;43(6):1511-1517.

11. Oldgren J, Alings M, Darius H, et al. Risks for stroke, bleeding, and death in patients with atrial fibrillation receiving dabigatran or warfarin in relation to the CHADS2 score: a subgroup analysis of the RE-LY trial. Ann Intern Med. 2011;155(10):660-667, W204.

12. Camm AJ, Lip GY, De Caterina R, et al. 2012 focused update of the ESC Guidelines for the management of atrial fibrillation: an update of the 2010 ESC Guidelines for the management of atrial fibrillation-developed with the special contribution of the European Heart Rhythm Association. Europace. 2012;14(10):1385-1413.

13. January CT, Wann LS, Alpert JS, et al. 2014 AHA/ACC/HRS guideline for the management of patients with atrial fibrillation: a report of the American College of Cardiology/American Heart Association Task Force on Practice Guidelines and the Heart Rhythm Society. J Am Coll Cardiol. 2014;64(21):e1-76.

14. Kearon C, Akl EA, Comerota AJ, et al. Antithrombotic therapy for VTE disease: Antithrombotic Therapy and Prevention of Thrombosis, 9th ed: American College of Chest Physicians Evidence-Based Clinical Practice Guidelines. Chest. 2012;141(2 Suppl):e419S-94S.

15. Kuroda Y, Hirayama C, Hotoda H, et al. Postmarketing safety experience with edoxaban in Japan for thromboprophylaxis following major orthopedic surgery. Vasc Health Risk Manag. 2013;9:593-598.

16. Ruff CT, Giugliano RP, Braunwald E, et al. Association between edoxaban dose, concentration, anti-Factor Xa activity, and outcomes: an analysis of data from the randomised, double-blind ENGAGE AF-TIMI 48 trial. Lancet. 2015;385(9984):2288-2295.

17. Said K. Hokusai-VTE: Edoxaban for the treatment of venous thromboembolism. Glob Cardiol Sci Pract. 2013;2013(4):416-420.

18. Ogata K, Mendell-Harary J, Tachibana M, et al. Clinical safety, tolerability, pharmacokinetics, and pharmacodynamics of the novel factor Xa inhibitor edoxaban in healthy volunteers. $J$ Clin Pharmacol. 2010;50(7):743-753.

19. Weitz JI, Connolly SJ, Patel I, et al. Randomised, parallel-group, multicentre, multinational phase 2 study comparing edoxaban, an oral factor $\mathrm{Xa}$ inhibitor, with warfarin for stroke prevention in patients with atrial fibrillation. Thromb Haemost. 2010;104(3):633-641.

20. Bathala MS, Masumoto H, Oguma T, et al. Pharmacokinetics, biotransformation, and mass balance of edoxaban, a selective, direct factor Xa inhibitor, in humans. Drug Metab Dispos. 2012;40(12):2250-2255.

21. Ruff CT, Giugliano RP, Antman EM, et al. Evaluation of the novel factor Xa inhibitor edoxaban compared with warfarin in patients with atrial fibrillation: design and rationale for the Effective aNticoaGulation with factor $\mathrm{xA}$ next GEneration in Atrial Fibrillation-Thrombolysis In Myocardial Infarction study 48 (ENGAGE AF-TIMI 48). Am Heart J. 2010;160(4):635-641. 
22. Go AS, Hylek EM, Phillips KA, et al. Prevalence of diagnosed atrial fibrillation in adults: national implications for rhythm management and stroke prevention: the AnTicoagulation and Risk Factors in Atrial Fibrillation (ATRIA) Study. JAMA 2001;285(18):2370-2375.

23. Lip GY, Nieuwlaat R, Pisters R, et al. Refining clinical risk stratification for predicting stroke and thromboembolism in atrial fibrillation using a novel risk factor-based approach: the euro heart survey on atrial fibrillation. Chest. 2010;137(2):263-272.

24. Chung N, Jeon HK, Lien LM, et al. Safety of edoxaban, an oral factor Xa inhibitor, in Asian patients with non-valvular atrial fibrillation. Thromb Haemost. 2011;105(3):535-544.

25. Yamashita T, Koretsune Y, Yasaka M, et al. Randomized, multicenter, warfarin-controlled phase II study of edoxaban in Japanese patients with non-valvular atrial fibrillation. Circ J. 2012;76(8):1840-1847.

26. Hogan H, Healey F, Neale G, et al. Preventable deaths due to problems in care in English acute hospitals: a retrospective case record review study. BMJ Qual Saf. 2012;21(9):737-745.

27. National Institute for Health and Clinical Excellence. NICE cost impact and commissioning assessment: quality standard for VTE prevention. Available from: https://www.nice.org.uk/guidance/qs3/resources/costimpact-and-commissioning-assessment-quality-standard-for-venousthromboembolism-vte-prevention-252274141. Accessed May 5, 2016.

28. National Institute for Health and Clinical Excellence. Venous thromboembolism: reducing the risk for patients in hospital. Available from: https://http://www.nice.org.uk/guidance/cg92. Accessed May 5, 2016.

29. Fuji T, Wang CJ, Fujita S, et al. Safety and efficacy of edoxaban, an oral factor Xa inhibitor, versus enoxaparin for thromboprophylaxis after total knee arthroplasty: the STARS E-3 trial. Thromb Res. 2014;134(6): 1198-1204.

30. Fuji T, Fujita S, Kawai Y, et al. Efficacy and safety of edoxaban versus enoxaparin for the prevention of venous thromboembolism following total hip arthroplasty: STARS J-V. Thromb J. 2015;13:27.
31. Robertson L, Kesteven P, McCaslin JE. Oral direct thrombin inhibitors or oral factor Xa inhibitors for the treatment of deep vein thrombosis. Cochrane Database Syst Rev. 2015;6:CD010956.

32. Fuji T, Fujita S, Kawai Y, et al. Safety and efficacy of edoxaban in patients undergoing hip fracture surgery. Thromb Res. 2014;133(6):1016-1022.

33. Christersson C, Wallentin L, Andersson U, et al. D-dimer and risk of thromboembolic and bleeding events in patients with atrial fibrillation--observations from the ARISTOTLE trial. J Thromb Haemost. 2014;12(9):1401-1412.

34. Hylek EM, Held C, Alexander JH, et al. Major bleeding in patients with atrial fibrillation receiving apixaban or warfarin: The ARISTOTLE Trial (Apixaban for Reduction in Stroke and Other Thromboembolic Events in Atrial Fibrillation): Predictors, Characteristics, and Clinical Outcomes. J Am Coll Cardiol. 2014;63(20):2141-2147.

35. Keeling D, Cotter F. Management of bleeding in patients taking FXa and FIIa inhibitors. Br J Haematol. 2013;160(1):1-2.

36. Shakur H, Roberts I, Bautista R, et al. Effects of tranexamic acid on death, vascular occlusive events, and blood transfusion in trauma patients with significant haemorrhage (CRASH-2): a randomised, placebo-controlled trial. Lancet. 2010;376(9734):23-32.

37. Nakamura M, Wang YQ, Wang C, et al. Efficacy and safety of edoxaban for treatment of venous thromboembolism: a subanalysis of East Asian patients in the Hokusai-VTE trial. J Thromb Haemost. 2015;13(9):1606-1614.

38. Caldeira D, Costa J, Ferreira JJ, et al. Non-vitamin K antagonist oral anticoagulants in the cardioversion of patients with atrial fibrillation: systematic review and meta-analysis. Clin Res Cardiol. 2015;104(7):582-590.

39. Loffredo L, Perri L, Del Ben M, et al. New oral anticoagulants for the treatment of acute venous thromboembolism: are they safer than vitamin $\mathrm{K}$ antagonists? A meta-analysis of the interventional trials. Intern Emerg Med. 2015;10(4):499-506.

40. Sardar P, Chatterjee S, Lavie CJ, et al. Risk of major bleeding in different indications for new oral anticoagulants: insights from a meta-analysis of approved dosages from 50 randomized trials. Int J Cardiol. 2015; 179:279-287.
Vascular Health and Risk Management

\section{Publish your work in this journal}

Vascular Health and Risk Management is an international, peerreviewed journal of therapeutics and risk management, focusing on concise rapid reporting of clinical studies on the processes involved in the maintenance of vascular health; the monitoring, prevention and treatment of vascular disease and its sequelae; and the involvement of

\section{Dovepress}

metabolic disorders, particularly diabetes. This journal is indexed on PubMed Central and MedLine. The manuscript management system is completely online and includes a very quick and fair peer-review system, which is all easy to use. Visit http://www.dovepress.com/ testimonials.php to read real quotes from published authors. 